\title{
Komparasi Nilai Ekonomi Air Irigasi dari Daerah Aliran Sungai Berhutan dan Tidak Berhutan
}

\author{
Purwanto ${ }^{1}$
}

1Balai Penelitian dan Pengembangan Teknologi Pengelolaan Daerah Aliran Sungai, Surakarta; e-mail: purwanto fris@yahoo.com

\begin{abstract}
ABSTRAK
Kawasan hutan di Indonesia banyak yang dikonversi menjadi penggunaan lain. Hal ini berdampak pada kondisi hidrologi dan nilai ekonomi air yang dihasilkannya. Penelitian ini menerapkan unit analisis Sub DAS dengan metode with and without penutupan hutan, Sub DAS Banjaran (berhutan) dan Sub DAS Cangkok (tidak berhutan). Desk analysis dilakukan untuk mengetahui penggunaan lahan, dilakukan pengumpulan data curah hujan, pengukuran debit sesaat untuk mengetahui debit kedua sungai pada saat musim kemarau, survey terhadap 15 orang petani pengguna air irigasi dari Sub DAS Banjaran dan 15 orang petani pengguna air irigasi dari Sub DAS Cangkok. Petani diwawancarai tentang faktor produksi dan produksi tanaman padi untuk mengetahui nilai ekonomi air dari kedua Sub DAS tersebut. Hasil kajian menunjukkan bahwa: 1). Curah hujan di Baturraden cukup tinggi (4.302 mm) tetapi untuk bulan Mei, Juli, Agustus dan September mengalami defisit untuk tanaman padi, 2). Sub DAS yang berhutan di Baturraden lebih mampu mengatur tata air dari pada sub DAS yang tidak berhutan, baik kualitas, kuantitas maupun kontinuitasnya, 3). Nilai ekonomi air untuk irigasi dari sub DAS yang berhutan sebesar Rp. Rp. 1.270,- $/ \mathrm{m}^{3}$ sedangkan nilai ekonomi air dari sub DAS yang tidak berhutan sebesar Rp. 373,5,-/ $\mathrm{m}^{3}$. Keberadaan hutan di dalam sub DAS sangat penting terhadap ekosistem DAS dan memiliki kualitas, kuantitas, dan nilai ekonomi hasil air yang lebih tinggi dari DAS yang tidak berhutan sehingga harus dilestarikan dengan mengikutsertakan masyarakat pengguna air dari Sub DAS berhutan tersebut.
\end{abstract}

Kata kunci: DAS berhutan, DAS tidak berhutan, nilai ekonomi air

\begin{abstract}
Many forest areas in Indonesia are converted to other uses. This will impact on the hydrological conditions and the economic value of the water yield. This research applied unit analysis of Sub watersheds, with and without forest cover, Sub DAS Banjaran (forested) and Sub CAS Cangkok (not forested). Desk analysis was conducted to know land use, collecting rainfall data, instantaneous debit measurement to know the discharge of both rivers during the dry season, survey of 15 farmers using irrigation water from Sub watershed of Banjaran (forested sub watershed) and 15 peasants who use irrigation water from Cangkok Sub watershed (non forested sub watershed). Farmers were interviewed about the factors of production and production of rice crops to determine the economic value of water from the two sub watersheds. The results of the study show that: 1). rainfall in Baturraden is quite high (4,302 $\mathrm{mm})$ but for May, July, August and September deficits for rice crops, 2). The forested sub-watershed in Baturraden is better able to regulate the water system than the non-forested sub-watershed, either quality, quantity or continuity, 3). The economic value of water for irrigation from the forested sub-watershed is Rp. 1,270,- $/ \mathrm{m}^{3}$ whereas from non-forested sub-watersheds Rp. 373.5,-/ $\mathrm{m}^{3}$. Baturraden forest is very important to the watershed ecosystem. Forested watershed was a higher quality, quantity. and economic value of water than non-forested ones so it must be conserved by involving the water user communities.
\end{abstract}

Keywords: forested watershed, non forested watershed, water economic value

Citation: Purwanto, P. (2019). Komparasi Nilai Ekonomi Air Irigasi dari Daerah Aliran Sungai Berhutan dan Tidak Berhutan. Jurnal Ilmu Lingkungan, 17(1),23-31, doi:10.14710/jil.17.1.23-31

\section{Pendahuluan}

Hutan merupakan tempat menyerapnya air hujan maupun embun yang pada akhirnya mengalirkannya ke sungai-sungai. Dengan adanya hutan, air hujan yang berlimpah dapat diserap dan disimpan di dalam tanah dan tidak terbuang percuma. Fungsi ini disebut juga sebagai fungsi hidrologis (Pudjiharta, 2008) dan (Kusumaningtyas \& Chofyan, 2012). Kondisi tersebut menyebabkan hutan dapat mengatur tata 
air sehingga mengeluarkan air yang terus menerus baik pada musim hujan maupun kemarau. Namun demikian, (Pudjiharta, 2008) menyatakan bahwa fungsi hutan dalam mengatur hidrologi sangat tergantung pada sifat curah hujan, tanah, geologi, dan lereng. Hutan dalam mengatur tata air tidak dapat berdiri sendiri, tetapi ada faktor-faktor di luar hutan (Pudjiharta, 2008). Menurut (Basuki \& Pramono, 2017) faktor di luar hutan tersebut antara lain: geologi dan geomorfologi. Geomorfologi dicerminkan oleh bentuk lahan dan kemiringan lahan. (Arnold, Allen, \& Bernhardt, 1993) dan (Pudjiharta, 2008) menyatakan bahwa yang terpenting untuk mengatur tata air adalah manajemen lahannya.

Kawasan hutan di Indonesia banyak yang dikonversi menjadi penggunaan lain. Pengaruh konversi tersebut terhadap kesehatan daerah aliran sungai (DAS) dan nilai ekonomi airnya, masih sedikit diteliti. Kajian yang banyak dilakukan yakni pengaruh konversi hutan terhadap tanah. (Widianto et al., 2004) menyatakan bahwa perubahan penggunaan lahan hutan menjadi kopi monokultur di Lampung mengakibatkan perubahan sifat tanah permukaan berupa penurunan bahan organik dan jumlah ruang pori. Alih guna lahan tersebut juga mengakibatkan penurunan ketebalan seresah dan jumlah pori makro tanah (Hairiah et al., 2004).

Air merupakan salah satu hasil hutan non kayu yang saat ini masih merupakan barang publik, belum merupakan barang ekonomi. Secara umum nilai ekonomi dapat diartikan sebagai karaketristik (kualitas) dari suatu barang dan jasa yang menyebabkan sesuatu tersebut dapat dipertukarkan dengan sesuatu yang lain (Alam, Supratman, \& Sahide, 2009). Sesuatu barang yang lain (other things) tersebut sangat menentukan harga atau manfaat suatu barang dan jasa. Di dalam terminologi finansial, nilai penukar dicerminkan oleh jumlah uang yang diterimakannya.

Nilai ekonomi sumberdaya air tergantung dari tingkat kelangkaannya. Kelangkaan diartikan sebagai jumlah barang yang diminta lebih banyak daripada barang yang ditawarkan atau yang tersedia (Suparmoko, 1997). Untuk melihat kelangkaan sumberdaya alam, para ahli ekonomi menggunakan berbagai cara antara lain: dengan menghitung harga barang sumberdaya alam dan nilai sewa ekonomik atau economic rent (Smith dalam Sumargo, 2002) atau satuan biaya produksi, royalty maupun elastisitas substitusi (Barnett dan Morse dalam Tahvonen, 2000).

Perhitungan nilai ekonomi air dari hutan telah dilakukan beberapa Peneliti. (Darusman, 1993) melaporkan nilai manfaat air yang diberikan Taman Nasional Gunung Gede Pangrango sebesar Rp. 4.341 milyar per tahun atau Rp. 280 juta per hektar per tahun. Nilai ini jauh lebih tinggi dari nilai hasil hutan tradisional (kayu). Laporan lain perhitungan nilai ekonomi air di Namimbia sebesar N \$ 0,64 (Macgregor, Masirembu, Williams, \& Munikasu, 2000). (Purwanto, Irfan Budi Pramono, S. Andy Cahyono, Agus Wuryanto, \& Sunaryo, 2009) menyatakan bahwa nilai ekonomi air dari hutan lindung Baturraden untuk : a). PLTA Ketenger sebesar Rp. 246.866.511,-/tahun, b). Irigasi Dam Karangnangka Rp. 1.432.993.162,-/tahun, c). Dam Beji Rp. 1.550.981.053,-/tahun, dan d). Dam Bobosan.

Ojea, Ortega, \& Chiabai, (2012) melaporkan nilai tangkapan air (Water capture value) = USD $₫$ $0.62 / \mathrm{m} 3$, nilai untuk kelestarian DAS (watershed protection value $)=$ USD $₫ 0.44 / \mathrm{m} 3$, nilai air untuk produksi sektor lain (water value for production) = USD \& 2.13/m3. (Budi, 2017) melaporkan kawasan hutan Gawalise (Palu) menghasilkan air 2.989.440 liter setiap hari atau 869.013.900 liter dalam setahun. Dengan asumsi harga pasar air adalah Rp. 3.207,00, maka nilai ekonomi yang dihasilkan kawasan hutan sebagai penyedia air adalah sebesar Rp. 3.499.303.939,20 per tahun (Budi, 2017). Kajian lainnya dilakukan oleh (Mutasodirin, 2014), potensi nilai ekonomi air yang terhitung di sumber air, di Hutan Pendidikan Gunung Walat, Sukabumi; sebesar Rp 120.803.468/bulan namun yang baru dikonsumsi masyarakat sebesar Rp 5.584.480/bulan.

Kajian ini menawarkan metode perhitungan nilai ekonomi hasil air dari Sub DAS (Sub Daerah Aliran Sungai) yang berhutan dan dari Sub DAS yang tidak berhutan atau sering disebut sebagai with and without method. Tujuan kajian ini adalah 1). Untuk mengetahui pengaruh hutan terhadap kuantitas dan kualitas hasil air dan 2). Untuk mengetahui nilai ekonomi hasil air dari Sub DAS yang berhutan dan Sub DAS yang tidak berhutan.

\section{Metode Penelitian \\ 2.1. Waktu dan Lokasi}

Penelitian dilakukan pada Mei September 2015. Waktu tersebut merupakan musim kemarau dimana terjadi kelangkaan air. Hal ini sesuai kaidah ekonomi sumberdaya, air memiliki nilai ekonomi apabila terjadi kelangkaan. Lokasi penelitian berada di Sub DAS Banjaran dan Sub DAS Cangkok. Sub DAS Banjaran, hulunya berada di hutan lindung Baturraden dan hilirnya berada di Desa Ketenger sedangkan Sub DAS Cangkok hulu sampai hilir berada di Desa Windusari, yang kedua Sub DAS tersebut berada di Kecamatan Baturraden, Kabupaten Banyumas (Gambar 1).

Lokasi penelitian dipilih 2 (dua) Sub DAS yakni Sub DAS Banjaran (hulunya merupakan hutan lindung Batu Radden) dan Sub DAS Cangkok (hulunya bukan hutan). Suhu udara terhangat di lokasi penelitian yakni $23.6^{\circ} \mathrm{C}$, terjadi pada bulan Oktober sedangkan suhu terendah terjadi pada bulan Juli yakni $22.4{ }^{\circ} \mathrm{C}$. 


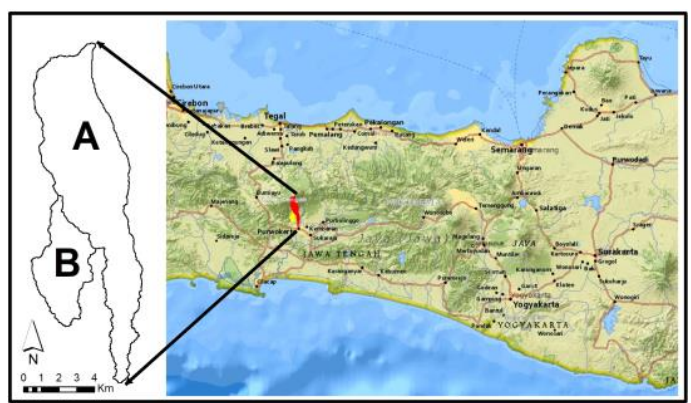

Keterangan: A. Sub DAS Banjaran dan B. Sub DAS Cangkok. Gambar 1. Lokasi Penelitian: Kecamatan Baturraden, Kabupaten Banyumas

Berdasarkan hasil pemetaan geologi oleh Rusmanto, et al (1999), Sub DAS Banjaran dan Sub DAS Cangkok merupakan bagian dari lembaran geologi Baturraden. Sifat geologi Baturraden, tanah lapukkannya umumnya tipis $<1 \mathrm{~m}$, sedangkan di lembah antar bukit $<2 \mathrm{~m}$, berupa lempung atau lempung-kerikil, warna: hitam, hitam kemerahan dan kecoklatan, agak plastis, agak lengket, lunak, permiabilitas sedang, daya dukung pada batuan $>150 \mathrm{~kg} / \mathrm{cm}^{2}$, pada permukaan bukit terbuka nampak lapukan batuan yang membentuk rekahan-rekahan yang mudah lepas sampai sangat rendah, air tanah dalam, jumlahnya terbatas yang dapat diperoleh pada daerah lembah atau zona pelapukan, muka air tanah umumnya dalam > 5 meter, air jernih, banyak muncul mata air dengan debit antara 10 100 lt/detik. Aliran sungai membentuk pola memancar (radier) yang berhulu di G. Slamet, aliran sungai mengalir cukup deras karena pengaruh gradien yang tinggi dan banyak membawa material batuan lepas berukuran pasir, kerakal hingga bongkah. Batu belah sebagai bahan bangunan sangat berlimpah dengan kualitas sangat baik, batuannya keras, kompak, dan pejal.

Bagian hulu Sub DAS Banjaran merupakan hutan lindung yang didominasi oleh jenis pohon dengan nilai penting (INP) sebagai berikut: Castanopsis argentea Blume (INP = 56,90\%), Elaeocarpus glaber Blume (INP = 45,86\%), Symplocos fasciculata Zoll. (INP = $33,42 \%$ ), Ficus fistulosa Reinw. (INP $=25,96 \%$ ), dan Antidesma tetandrum Blume (INP $=16,26 \%$ ) (Kalima, 2007). Sub DAS Cangkok didominasi oleh tegalan yang ditanami pola agroforestry dengan jenis tanaman semusim dan tanaman tahunan yang didominasi sengon (Paraserianthes falcataria). Sawah di kedua sub DAS dapat ditanami padi, 3 (tiga) musim tanam setahun.

\subsection{Pengumpulan Data}

Penelitian ini terdiri: 1). desk analysis untuk mengetahui penggunaan lahan di Sub DAS Banjaran dan Sub DAS Cangkok, 2. Pengumpulan data curah hujan yang diukur oleh staf Bagian Kesatuan Pemangkuan Hutan (BKPH) Gunung Slamet Barat, di Baturraden, 3. Pengukuran debit dan pengambilan sampel air Sungai Banjaran dan
Sungai Cangkok untuk mengetahui kuantitas (debit) dan kualitas air, dan 4. Survey untuk mengetahui input dan output usaha tani padi yang menggunakan air irigasi dari kedua Sub DAS. Desk analysis di Laboratorium Geography Information System (GIS) Balai Penelitian dan Pengembangan Teknologi Pengelolaan Daerah Aliran Sungai, Surakarta.

Pengukuran debit dilakukan dengan metode langsung yakni dilakukan pengukuran penampang sungai dan kecepatan air sungai. Pengukuran dilakukan debit air sungai Sungai Banjaran dan Sungai Cangkok dilakukan setiap hari pada pukul 07.00 WIB, pada Bulan Mei September, setiap tanggal 1 dan 15. Pengukuran debit air dan pengambilan sampel untuk kualitas air dilakukan di outlet hutan lindung Sub DAS Bajaran dan non hutan lindung Sub DAS Cangkok. Di sisi lain, untuk mengetahui perbandingan kualitas air di kedua Sub DAS (berhutan dan tidak berhutan) dilakukan pengambilan sampel air pada tanggal 15 September 2015 dimana terjadi puncak musim kemarau. Pengambilan sampel air hanya dilakukan sekali karena keterbatasan anggaran. Sampel air kemudian dianalisis di Laboratorium Balai Besar Teknik Kesehatan Lingkungan dan Pengendalian Penyakit, Yogyakarta.

Data faktor produksi dan produksi usaha tani sawah yang menggunakan air dari hutan lindung (Sub DAS Banjaran) dan sawah yang tidak menggunakan air dari hutan (Sub DAS Cangkok) dikumpulkan melalui survey. Survey usaha tani dilakukan di Desa Ketenger dan Windusari, Kecamatan Baturaden. Jumlah sampel petani masing-masing sebanyak 15 petani sehingga jumlah sampelnya menjadi 30 orang. Faktor usaha tani terdiri dari: luas usaha tani, pengeluaran untuk bibit, pengeluaran untuk pupuk, pengeluaran untuk insektisa, pengeluaran untuk tenaga kerja, kebutuhan air irigasi sedangkan produk usaha tani yakni berat gabah kering. Kebutuhan air irigasi diperoleh dari pengukuran debit air yang masuk ke bidang sawah. Pengukuran dilakukan seminggu sekali.

\subsection{Pengolahan Data}

Data penutupan lahan dari Peta Rupa Bumi Indonesia dihitung luas masing-masing penggunaan lahan dan dibuat peta penggunaan lahan. Rata-rata bulanan curah hujan dan debit air sungai diolah dari data curah hujan dan debit harian. Hasil analisis sampel air dari Balai Teknik Kesehatan Lingkungan dan Pemberantasan Penyalit Menular Yogyakarta, dilakukanan analisis berdasarkan Peraturan Pemerintah No. 82 Tahun 2001 tentang Pengelolaan Kualitas Air dan Pengendalian Pencemaran Air (Pemerintah Republik Indonesia, 2001). Untuk mengetahui nilai ekonomi air irigasi pada masing-masing lokasi (Sub DAS Banjaran dan Cangkok) dihitung dengan menggunakan fungsi produksi Cobb Douglas (Soekartawi, 2014). 


\section{$\mathbf{Y}_{\mathrm{i}}=\mathbf{a X}_{1} \mathbf{b}^{\mathrm{b}} \mathbf{X}_{2} \mathbf{C X}_{3}{ }^{\mathrm{d}} \mathbf{X}_{4} \mathrm{eX}^{\mathrm{f}} \mathbf{X}_{6} \mathrm{~g}$}

Dimana $Y_{i}$ adalah pendapatan usaha tani responden ke $\mathrm{i}, \mathrm{X}_{1}$ adalah luas usaha tani, $\mathrm{X}_{2}=$ pengeluaran untuk bibit, $X_{3}=$ pengeluaran untuk pupuk, $X_{4}=$ pengeluaran untuk insektisa, $X_{5}$ adalah pengeluaran untuk tenaga kerja, dan $\mathrm{X}_{6}=$ kebutuhan air irigasi. Karena seluruh input dan output diketahui finansialnya kecuali kebutuhan air maka nilai ekonomi air dapat diketahui. Besarnya kebutuhan air irigasi dihitung berdasarkan atas hasil kajian sebelumnya untuk masing-masing jenis tanaman (Dumairy, 1987). Dalam perhitungannya luas lahan disamakan menjadi 1 ha sehingga luas lahan tidak menjadi variabel dan persamaan menjadi: $\mathbf{Y}_{\mathbf{i}}=$ $\mathbf{a X}_{2}{ }^{\mathbf{b}} \mathbf{X}_{3} \mathbf{c} \mathbf{X}_{4}{ }^{\mathbf{d}} \mathbf{X}_{5} \mathbf{X}^{\mathbf{e}} \mathbf{X}_{6} \mathbf{f}$. Harga air per $\mathrm{m}^{3}$ untuk masing Sub DAS (Banjaran dan Cangkok) dihitung berdasarkan elastisitas dari parameter air $\mathrm{x}$ harga padi kering per kg.

\section{Hasil dan Pembahasan}

\subsection{Penggunaan Lahan di Sub DAS Banjaran dan Sub DAS Cangkok}

Tataguna lahan di kedua sub DAS tersebut di sajikan pada Gambar 2 dengan luas penggunaan lahan disajikan pada Tabel 1. Dari Gambar 2. dan Tabel 1. dapat dilihat bahwa kawasan hutan lindung Baturraden mendomoniasi $(54,56 \%)$ penggunaan lahan di Sub DAS Banjaran sedangkan di Sub DAS Cangkok tidak memiliki kawasan hutan (0\%). Berdasarkan Undang-undang No. 41 Tahun 1999 tentang Kehutanan (Presiden Republik Indonesia, 1999), dalam penjelasan pasal 18 ayat 2 disebutkan bahwa luas hutan di suatu DAS minimal 30\% dari luas DAS. Hal ini menunjukkan bahwa luas hutan di Sub DAS Banjaran, telah mencukupi untuk mempertahankan kelestarian ekosistem DAS dari segi tata air sedangkan Sub DAS Cangkok diperlukan pengkayaan vegetasi permanennya.

Tabel 1. Penggunaan Lahan di Sub DAS Banjaran dan Cangkok

\begin{tabular}{|c|c|c|c|}
\hline \multirow[t]{2}{*}{ No. } & \multirow{2}{*}{$\begin{array}{l}\text { Penggunaan } \\
\text { Lahan }\end{array}$} & \multicolumn{2}{|c|}{ Name/Luas/Area (Ha) } \\
\hline & & $\begin{array}{l}\text { Sub DAS } \\
\text { Banjaran }\end{array}$ & $\begin{array}{l}\text { Sub DAS } \\
\text { Cangkok }\end{array}$ \\
\hline 1. & Hutan lindung & $2.016,90$ & 0 \\
\hline 2. & Kebun & 739,02 & 824,28 \\
\hline 3. & Pemukiman & 204,78 & 268,20 \\
\hline 4. & Tanah kosong & 4,55 & 0 \\
\hline 5. & Semak Belukar & 351,41 & 8,72 \\
\hline 6. & Sawah & 367,21 & 300,45 \\
\hline 7. & Ladang & 12,44 & 6,32 \\
\hline \multirow[t]{2}{*}{8.} & Lain-lain & 0,44 & 0,12 \\
\hline & Total & $3.696,75$ & $1.407,09$ \\
\hline
\end{tabular}

Sumber: Peta Rupa Bumi Indonesia dan Cheking Lapangan

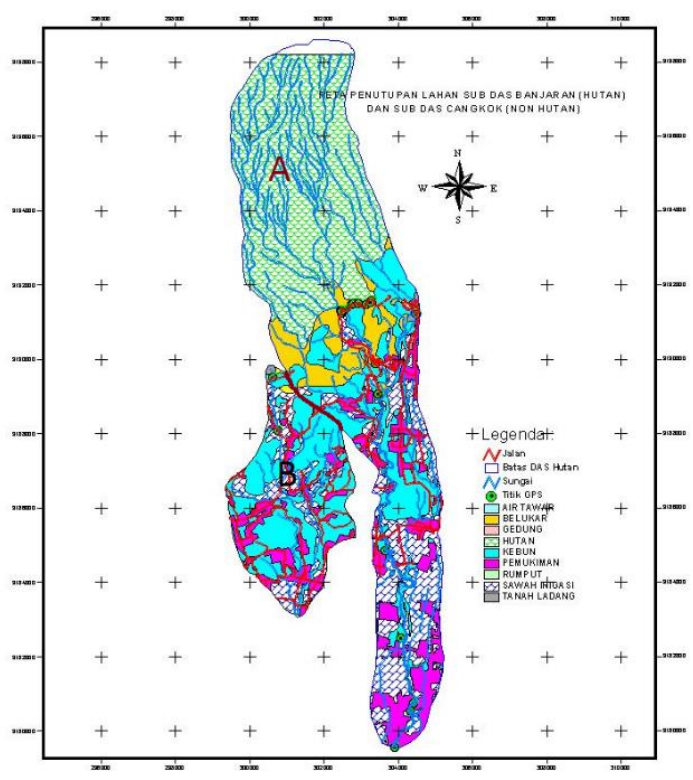

Keterangan: A = Sub DAS Banjaran, B = Sub DAS Cangkok Sumber: Peta Rupa Bumi Indonesia dan Cheking Lapangan Gambar 2. Tataguna Lahan Sub DAS Banjaran dan Sub DAS Cangkok

\subsection{Curah hujan dan Kebutuhan Air untuk Tanaman Padi}

Berdasarkan data curah hujan yang diukur di Baturraden, curah hujan tahunan pada tahun 2015 sebesar $4.302 \mathrm{~mm}$. Pola hujan di Baturraden dapat dikategorikan sebagai pola monsunal yang dicirikan oleh tipe curah hujan yang bersifat unimodial. Pola hujan monsunal digerakkan oleh adanya sel tekanan tinggi dan sel tekanan rendah di benua Asia dan Australia secara bergantian (Hermawan, 2010). Lebih lanjut, (Hermawan, 2010) menyatakan bahwa daerah yang memiliki pola curah hujan monsunal berada di Sumatera bagian selatan, Kalimantan Tengah dan Kalimantan Selatan, Jawa, Bali, Nusa Tenggara, dan sebagian Papua.

Pola hujan monsunal ada yang memiliki satu puncak musim hujan yang disebut unimodial seperti di Baturraden dimana pada bulan Juli, Agustus dan September terjadi musim kering, sedangkan untuk bulan Desember, Januari dan Februari merupakan bulan basah. Sebagai bahan perbandingan, di Morotae, memiliki pola hujan monsunal tetapi memilki 2 (dua) puncak musim hujan yakni pada bulan Januari dan Juni (Visa \& Harjana, 2015).

Hubungan antara curah hujan dan kebutuhan air tanaman padi (Orysa satifa) disajikan pada Tabel. 2. Berdasarkan Tabel 2, di Desa Windusari dan Desa Ketenger mulai Bulan April s/d Agustus terjadi defisit air untuk tanaman padi apabila hanya mengandalkan curah hujan. Untuk mengatasi defisit air tersebut dilakukan usaha padi sawah dengan sistem irigasi. 
Tabel 2. Musim tanam, curah hujan dan kebutuhan air tanaman padi (O. satifa) di Desa Ketenger dan Windusari, Kecamatan Baturraden

\begin{tabular}{|c|c|c|c|c|}
\hline Musim tanam/bulan & $\begin{array}{l}\text { Curah hujan bulanan } \\
\text { (mm) }\end{array}$ & Kebutuhan air (mm) & Surplus/defisit (+/-) $\left.\mathrm{mm}^{*}\right)$ & Keterangan \\
\hline \multicolumn{5}{|l|}{ I } \\
\hline Nopember & 397 & 309,8 & 87,2 & surplus \\
\hline Desember & 520 & 312,0 & 208,0 & surplus \\
\hline Januari & 709 & 322,4 & 386,6 & surplus \\
\hline Pebruari & 616 & 23,8 & 592,2 & surplus \\
\hline \multicolumn{5}{|l|}{ II } \\
\hline Maret & 586 & 309,8 & 276,2 & surplus \\
\hline April & 415 & 312,0 & 103,0 & surplus \\
\hline Mei & 280 & 322,4 & $-42,4$ & defisit \\
\hline Juni & 160 & 23,8 & 136,2 & surplus \\
\hline \multicolumn{5}{|l|}{ III } \\
\hline Juli & 132 & 309,8 & $-177,8$ & defisit \\
\hline Agustus & 114 & 312,0 & $-198,0$ & defisit \\
\hline September & 127 & 322,4 & $-195,4$ & defisit \\
\hline Oktober & 246 & 23,8 & 222,2 & surplus \\
\hline Total & 4.302 & 3.872 & 430 & surplus \\
\hline
\end{tabular}

*). Kebutuhan air untuk tanaman padi (O. satifa) berdasarkan Dumairy (1987).

Sumber: data dikumpulkan dari penangkar cura hujan stasiun Perum Perhutani, BKPH Gunung Slamet Barat, Baturraden, 2015

\subsection{Debit dan Kualitas Air}

\subsubsection{Debit Air Sungai Banjaran dan Cangkok Pada Musim Kemarau}

Debit air sungai yang diukur bersamaan pada musim kemarau, untuk S. Banjaran memiliki rata-rata sebesar 5,162 m3/detik dan S. Cangkok sebesar 0,779 m3/detik. Volume air yang dialirkan oleh Sungai Banjaran selama bulan Mei September sebesar ( 153 x $24 \times 60 \times 60$ detik) x $5,162 \mathrm{~m} 3 /$ detik $=68.237 .510,4 \mathrm{~m} 3$ dan untuk Sungai Cangkok sebesar (153 x $25 \times 60 \times 60$ detik) x 0,779 m3/detik $=10.297 .756,8 \mathrm{~m} 3$. Luas lahan di Sub DAS Banjaran adalah 3.696,75 ha dan Sub DAS Cangkok 1.407,09 ha, sehingga debit spesifiknya, untuk Sub DAS Banjaran $=((5,162 \mathrm{x}$ 1.000) liter $/$ detik $) / 3.696,75$ ha $=1,40$ liter/detik/ha sedang- kan untuk Sub Das Cangkok $=((0,779 \times 1.000)$ liter $/$ detik $) / 1.407,09$ ha $=0,55$ liter $/$ detik $/$ ha. Hal ini menunjukkan bahwa sub DAS yang berhutan lebih mampu mengatur tata air dibanding dengan Sub DAS yang tidak berhutan. Hal ini sesuai dengan pendapat (Sylviani, 2008), hasil air dari hutan lindung lebih tinggi dari pada hasil air dari hutan tanaman; (Pudjiharta, 2008) kondisi hutan yang baik (kuantitas dan kualitas) hutan dapat meningkatkan fungsi hutan sebagai pengendali aliran; dan (Hlásny, Sitková, \& Barka, 2013) menyatakan bahwa struktur dan distribusi hutan di dalam Daerah Aliran Sungai berpengaruh terhadap kualitas, kuantitas, dan kontinuitas air sungai.

\subsubsection{Kualitas air dari Sub DAS Berhutan (Banjaran) dan Sub DAS Tidak Berhutan (Cangkok)}

Berdasarkan analisis kualitas air (Tabel 3), diperoleh beberapa parameter yang berbeda akibat penggunaan lahan yang berbeda. Parameter tersebut antara lain suhu udara, residu terlarut, $\mathrm{pH}, \mathrm{BOD}$, nitrat, ammonia, besi, chloride, dan sulfat. Air dari Sub DAS yang berhutan (Banjaran) memiliki suhu lebih rendah dibanding Sub DAS yang tidak berhutan (Cangkok). (Brown \& Krygier, 1970) dan (Moore, Story, \& Spittlehouse, 2005) menyatakan bahwa ekosistem hutan dapat menjaga kondisi iklim mikro sehingga bila dilakukan penebangan tegakannya dapat meningkatkan radiasi sinar mata hari ke dasar lantai hutan dan meningkatkan suhu udara akibatnya dapat berpengaruh terhadap suhu udara hasil air dari hutan. Residu terlarut hasil air dari Sub DAS yang tidak berhutan (Sub DAS Cangkok) lebih tinggi dibanding residu terlarut dari Sub DAS yang berhutan (Sub DAS Banjaran). Hal ini karena residu terlarut merupakan partikel sedimen terlarut yang berasal dari erosi tanah. Pada lahan yang tertutup 
hutan memiliki erosi yang lebih kecil dibanding dengan lahan untuk pertanian lahan kering yang mendominasi DAS Cangkok.

Bahan pencemar dari Sub DAS Cangkok ( tidak berhutan) diduga berasal dari penggunaan pupuk untuk faktor produksi usaha tani. Nitrat dan ammonia berasal dari residu pupuk urea, chlorite berasal dari pupuk $\mathrm{KCl}$ dan sulfat berasal dari pupuk TSP. (Uly, Marsudi, \& Jati, 2001) menyatakan bahwa penggunaan pupuk anorganik menghasilkan residu yang dapat menyebabkan penurunan kualitas air tanah. Bahan pencemar di dalam air tanah mengalir ke sungai sehingga menyebabkan pencemaran air sungai. (Jana, Sudarmanto, \& Rusminingsih, 2014) menyatakan bahwa pengaruh penggunaan pupuk dapat meningkatkan bahan pencemar air sungai yang makin ke hilir konsentarsinya semakin tinggi.

Kondisi tersebut menunjukkan bahwa Sub DAS yang berhutan lebih mampu mengendalikan bahan pencemar sehingga hasil air dari hutan lindung yang masuk ke sungai tidak tercemar. Pendapat ini sesuai dengan (Brogna et al., 2017) bahwa besarnya penutupan hutan berpengaruh terhadap kualitas hasil air. Lebih detail, residu terlarut dan sedimen menunjukkan indeks degradasi lahan, tingkat dan tren kekritisan DAS dan juga mencerminkan karakteritik suatu DAS (Lane, Hernandez, \& Nichols, 1997), (Verstraeten \& Poesen, 2001), (Lu, Moran, \& Sivapalan, 2005), dan (Sadeghi \& Saeidi, 2010).

Kajian yang menyatakan bahwa penggunaan lahan non hutan (lahan pertanian) dapat berdampak pada badan air disampaikan oleh (Divya \& Belagali, 2012), yang menyatakan bahwa akibat penggunaan pupuk kimia di lahan pertanian Mysore District, Karnataka, India, menyebabkan residu urea di badan air sungai 0,1 - 0,12 ppm dan terakumulasi di badan air danau sedangkan kandungan klorit di badan air sungai 20.89 to $97.00 \mathrm{mg} / \mathrm{l}$. Kandungan klorit berada di atas ambang batas yang diperkenankan. Hasil kajian lainnya (Murtiono \& Wuryanta, 2016) menyatakan penyumbang eutrofikasi tertinggi di Waduk alam Rawapening berasal dari lahan sayur (591,923 ton/th atau 62,06\%).

Tabel 3. Sifat fisika dan kimia air dari Sub DAS yang berhutan dan Sub DAS yang tidak berhutan

\begin{tabular}{|c|c|c|c|c|c|c|}
\hline \multirow[t]{2}{*}{ No. } & \multirow[t]{2}{*}{ Parameter } & \multirow[t]{2}{*}{ Satuan } & \multicolumn{2}{|c|}{ Asal sampel } & \multirow[t]{2}{*}{ Standar } & \multirow[t]{2}{*}{ Metode uji } \\
\hline & & & $\begin{array}{l}\text { Sub DAS } \\
\text { berhutan }\end{array}$ & $\begin{array}{l}\text { Sub DAS } \\
\text { tanpa hutan }\end{array}$ & & \\
\hline 1. & Temperatur & ${ }^{\circ} \mathrm{C}$ & 30 & 32 & Deviasi 3 & IK/BBTKLPPM/3-K/Pjc-01 \\
\hline 2. & Residu terlarut & $\mathrm{mg} / \mathrm{l}$ & 95 & 349 & 1000 & In House Methode \\
\hline 3. & Residu tersuspensi & $\mathrm{mg} / \mathrm{l}$ & 1 & 1 & 50 & In House Methode \\
\hline 4. & $\mathrm{PH}$ & - & 6,8 & 7,6 & $6-9$ & IK/BBcTKLPPM/3-K/Pjc-02 \\
\hline 5. & BOD & $\mathrm{mg} / \mathrm{l}$ & 1,5 & 2,1 & 2 & SNI 06-2503-1991 \\
\hline 6. & COD & $\mathrm{mg} / \mathrm{l}$ & 8 & 8 & 10 & APHA 1998, Section 5220 \\
\hline 7. & DO & $\mathrm{mg} / \mathrm{l}$ & 4,8 & 5,0 & 6 & SNI 06-2503-1991 \\
\hline 8. & Total Fosfat sbg P & $\mathrm{mg} / \mathrm{l}$ & - & - & 0,2 & - \\
\hline 9. & Nitrat $\left(\mathrm{NO}_{3}\right)$ & $\mathrm{mg} / \mathrm{l}$ & $<0,06$ & 0,22 & 10 & APHA 1998, Section 4500-NO3-B \\
\hline 10. & Amonia $\left(\mathrm{NH}_{3}\right)$ & $\mathrm{mg} / \mathrm{l}$ & 0,0038 & 0,0108 & 0,5 & SNI 06-2479-1991 \\
\hline 11. & Arsen (As) & $\mathrm{mg} / \mathrm{l}$ & - & - & 0,05 & SNI 06-2463-1991 \\
\hline 12. & Kobalt (Co) & $\mathrm{mg} / \mathrm{l}$ & - & - & 0,2 & SNI 06-2471-1991 \\
\hline 13. & Boron (B) & $\mathrm{mg} / \mathrm{l}$ & - & - & 1 & APHA 1998, Section 4500-B-C \\
\hline 14. & Kadnium (Cd) & $\mathrm{mg} / \mathrm{l}$ & - & - & 0,01 & SNI 06-2464-1991 \\
\hline 15. & Krom (Cr) & $\mathrm{mg} / \mathrm{l}$ & - & - & 0,05 & APHA 1998 , Section 3500-Cr-B \\
\hline 16. & Tembaga (Cu) & $\mathrm{mg} / \mathrm{l}$ & - & - & 0,02 & SNI 06-2514-1991 \\
\hline 17. & Besi (Fe) & $\mathrm{mg} / \mathrm{l}$ & $<0,03$ & 0,11 & 0,3 & SNI 19-1127-1989 \\
\hline 18. & Timbal $(\mathrm{Pb})$ & $\mathrm{mg} / \mathrm{l}$ & - & - & 0,03 & SNI 06-2517-1991 \\
\hline 19. & Mangan (Mn) & $\mathrm{mg} / \mathrm{l}$ & - & - & 0,1 & SNI 19-1133-1989 \\
\hline 20. & Air raksa $(\mathrm{Hg})$ & $\mathrm{mg} / \mathrm{l}$ & - & - & 0,001 & SNI 06-2462-1991 \\
\hline 21. & Seng $(\mathrm{Zn})$ & $\mathrm{mg} / \mathrm{l}$ & - & - & 0,05 & SNI 06-2507-1991 \\
\hline 22. & Clorida (Cl) & $\mathrm{mg} / \mathrm{l}$ & 1,0 & 66,0 & - & SNI 06-2431-1991 \\
\hline 23. & Sianida (CN) & $\mathrm{mg} / \mathrm{l}$ & tdk terde & tdk terde & 0,02 & APHA 1998, Section 4500-CN-E \\
\hline 24. & Fluorida (F) & $\mathrm{mg} / \mathrm{l}$ & 0,23 & 0,19 & 0,5 & APHA 1998, Section 4500-F-D \\
\hline 25. & Nitrit (NO2) & $\mathrm{mg} / \mathrm{l}$ & $<0,0007$ & 0,0042 & 0,06 & SNI 06-2484-1991 \\
\hline 26. & Sulfat $\left(\mathrm{SO}_{4}\right)$ & $\mathrm{mg} / \mathrm{l}$ & 3 & 64 & 400 & SNI 06-2426-1991 \\
\hline 27. & Khlor bebas & $\mathrm{mg} / \mathrm{l}$ & 0,0 & 0,0 & 0,03 & SNI 06-2431-1991 \\
\hline 28. & Belerang sbg $\mathrm{H}_{2} \mathrm{~S}$ & $\mathrm{mg} / \mathrm{l}$ & Tdk terde & tdk terde & 0,002 & SNI 19-1664-1989 \\
\hline 29. & Minyak lemak Deterjen & $\mathrm{mg} / \mathrm{l}$ & - & - & 1000 & - \\
\hline 30. & sbg MBAS & $\mathrm{mg} / \mathrm{l}$ & 0,1518 & 0,2983 & 200 & SNI 06-2476-1991 \\
\hline 31. & Senyawa Fenol & $\mathrm{mg} / \mathrm{l}$ & 0,0254 & 0,0399 & & SNI 19-2469-1991 \\
\hline
\end{tabular}

Sumber: 1. Dianalisis di Laboratorium Balai Teknik Kesehatan Lingkungan dan Pemberantasan Penyalit Menular Yogyakarta dan 2. Analisis didasarkan pada Peraturan Pemerintah No. 82 Tahun 2001 tentang Pengelolaan Kualitas Air dan Pengendalian Pencemaran Air 


\subsubsection{Komparasi Nilai Ekonomi Air Irigasi dari Hutan Lindung dan Non Hutan Lindung}

Persamaan hubungan produksi dan faktor produksi usaha tani padi yang mendapatkan air dari hutan lindung adalah $\mathrm{Y}_{\mathrm{hl}}=7,07592$ $\mathrm{X}_{2}{ }^{0,508109} \mathrm{X}_{3}{ }^{0,057593} \mathrm{X}_{4}{ }^{-0,209702} \mathrm{X}_{5}{ }^{-0.063811} \mathrm{X}_{6}{ }^{-0,295340}$ dan non hutan lindung adalah $\mathrm{Y}_{\mathrm{nhl}}=-2.039942$ $\mathrm{X}_{2}{ }^{1,939903} \quad \mathrm{X}_{3}{ }^{0,035012} \mathrm{X}_{4}^{-0,005778} \mathrm{X}_{5}{ }^{0,239590} \mathrm{X}_{6}{ }^{0,086850}$. Berdasarkan harga gabah kering giling jenis logawa yakni Rp. 4.300,-/kg maka nilai ekonomi air untuk irigasi dari sub DAS yang berhutan sebesar 0,295340 x Rp. 4.300,- atau Rp. 1.270,/m3 sedangkan yang dari non hutan sebesar 0,086850 x Rp. 4.300,- = Rp. 373,5,-/m3. Defisit air untuk irigasi pada Bulan Mei (- 42,4 mm), Juli (- 177,8 mm), Agustus $(-198,0 \mathrm{~mm})$ dan September (- 195,4 mm) (lihat Tabel 2), maka untuk luasan sawah 1 ha mengalami defisit air = $(42,4+177,8+198,0+195,4) \mathrm{mm} \times 10.000 \mathrm{~m} 2=$ $613,6 \mathrm{~mm} \times 10.000 \mathrm{~m} 2=0,6136 \times 10.000 \mathrm{~m} 3=$ $6.136 \mathrm{~m} 3 /$ ha. Apabila air tersebut dialirkan dari S. Banjaran yang hulunya merupakan hutan lindung maka nilai ekonomi air $=6.136 \mathrm{~m} 3 /$ ha $\mathrm{x}$ Rp. 1.270,-/m3 = Rp. 7.792.720,-/ha dan bila dialirkan dari Sub DAS Cangkok yang hulunya bukan hutan memiliki nilai ekonomi $=6.136 \mathrm{~m} 3 /$ ha $\mathrm{x} \mathrm{Rp}$. 373,5,-/m3 = Rp. 2.291.796,-/ha.

Dari uraian di atas menunjukkan bahwa untuk usaha tani padi bila menggunakan air irigasi dari hutan mimiliki nilai ekonomi lebih tinggi dibanding hasil air non hutan. Karena selama ini penggunaan air irigasi tidak dikenai biaya maka temuan ini dapat digunakan sebagai bahan penyuluhan kepada petani, bahwa nilai ekonomi air dari hutan memiliki nilai ekonomi yang tinggi sehingga masyarakat dapat berperan aktif dalam pelestarian hutan.

\section{Kesimpulan dan Saran \\ 4.1. Kesimpulan}

1. Sub DAS yang berhutan mampu mengatur tata air dari pada sub DAS yang tidak berhutan, baik kualitas, kuantitas maupun kontinuitasnya.

2. Nilai ekonomi air untuk irigasi dari Sub DAS yang berhutan hutan lindung sebesar Rp. Rp. $1.270,-/ \mathrm{m} 3 / \mathrm{m} 3$ sedangkan sub DAS non hutan sebesar Rp. 373,5,-/m3 pada musim kemarau yang digunakan untuk irigasi padi sawah.

\subsection{Saran}

Ekosistem hutan di suatu Sub DAS perlu dilestarikan bersama masyarakat pengguna air untuk menjaga kualitas, kuantitas, maupun nilai ekonomi hasil air.

\section{UCAPAN TERIMA KASIH}

Dengan rendah hati, penulis mengucapkan terima kasih kepada: 1. Dr. Nur Sumedi, SP, MSc, Kepala Balai Penelitian dan Pengembangan Teknologi Pengelolaan Daerah Aliran Sungai, Surakarta yang telah memberi kepercayaan kepada penulis untuk melakukan penelitian ini, 2 . Teman-teman teknisi Lab GIS dan teknisi hidrologi yang telah membantu pengumpulan data dan pengolahan data, 3. Kepala Bagian Kesatuan Pemangkuan Hutan Gunung Slamet Barat dan staf yang mengijinkan penulis untuk melakukan penelitian di wilayah kerjanya, membantu pengukuran curah hujan dan sebagai petunjuk dalam menentukan lokasi kajian, 4. Kepala Desa Ketenger dan Kepala Desa Windusari yang telah mengijinkan penulis melakukan survey dan wawancara kepada masyarakat, 5. Petani Ketenger dan Windusari yang telah bersedia untuk diwawancarai dan memberikan informasi yang diperlukan, dan 6. Kepala Balai Besar Teknik Kesehatan Lingkungan dan Pengendalian Penyakit, Yogyakarta; yang telah membantu analisis kimia sampel air dari lokasi penelitian.

\section{DAFTAR PUSTAKA}

Alam, S., Supratman, \& Sahide, M. A. K. (2009). Ekonomi sumberdaya hutan (I). Tamalanrea. Retrieved from

https://mimpi22.files.wordpress.com/2013/04/ buku-ajar-esdh-2009.pdf

Arnold, G. J., Allen, P. M., \& Bernhardt, G. (1993). A comprehensive surface-groundwater flow model. Journal of Hydrology, 142(1-4), 47-69. https://doi.org/https://doi.org/10.1016/00221694(93)90004-S

Basuki, T. M., \& Pramono, I. B. (2017). Hutan Jati Tempat Tumbuh, Hasil Air dan Sedimen. (P. Sudira \& P. Hadi, Eds.) (I). Surakarta: UNS Press.

Brogna, D., Michez, A., Jacobs, S., Dufrêne, M., Vincke, C., \& Dendoncker, N. (2017). Linking Forest Cover to Water Quality: A Multivariate Analysis of Large Monitoring Datasets. Ecological Indicators, 72, 675-685. Retrieved from https://app.dimensions.ai/details/publication/p ub.1034178273

Brown, G. W., \& Krygier, J. T. (1970). Effects of Clear-Cutting on Stream Temperature. Water Resources Research, 6(4), 1133-1139. https://doi.org/10.1029/WR006i004p01133

Budi, H. P. (2017). Valuasi Ekonomi Fungsi Hidrologis Kawasan Hutan Lindung Gunung Gawalise Sebagai Penyedia Kebutuhan Air Bagi Masyarakat Di Wilayah Kecamatan Ulujadi Kota Palu. Jurnal Katalogis, 5(3), 127-136. Retrieved from http://jurnal.untad.ac.id/jurnal/index.php/Katal ogis/article/view/8689

Darusman, D. (1993). Ekonomi Air untuk Pertanian dan Rumah Tangga Studi Kasus di Sekitar Taman Nasional Gunung Gede-Pangrango. In Prosiding Simposium Nasional Permasalahan Air di Indonesia (pp. 189-201). Bandung: Institut Teknologi Bandung. Retrieved from http://repository.ipb.ac.id/handle/123456789/2 4203

Divya, J., \& Belagali, S. . (2012). Impact of chemical fertilizers on water quality in selected agricultural areas of Mysore district, Karnataka, India. International Journal of Environmental Sciences, 2(3), 1449-1458. https://doi.org/10.6088/ijes.00202030030

Dumairy. (1987). Ekonomika Air (I). Yogyakarta: BPFE. 
Hairiah, K., Suprayogo, D., Suhara, E., Mardiastuning, A., Widodo, R. H., Prayogo, C., \& Rahayu, S. (2004). Alih Guna Lahan Hutan Menjadi Lahan Agroforestry Berbasis Kopi: Ketebalan Serasah, Populasi Cacing Tanah, dan Makroporositas Tanah. Agrivita, Jurnal Tentang Ilmu-Ilmu Pertanian, 26(1), 68-80. Retrieved from https://www.worldagroforestry.org/region/sea/ .../download

Hermawan, E. (2010). Pengelompokkan Pola Curah Hujan yang Terjadi di Beberapa Kawasan Pulau Sumatera berbasis Hasil Analisis Teknik Spektral. Jurnal Meteorologi Dan Geofisika, 11(2), 75-85. Retrieved from http://puslitbang.bmkg.go.id/jmg/index.php/JM G/article/viewFile/67/61

Hlásny, T., Sitková, Z., \& Barka, I. (2013). Regional assessment of forest effects on watershed hydrology: Slovakia as a case study. Journal of Forest Science, 59(10), 405-415.

Jana, I. W., Sudarmanto, I. G., \& Rusminingsih, N. K. (2014). Pengauh Aktivitas Pertanian Terhadap Kualitas Air Irigasi Di Subak Tegalampit Payangan, Gianyar, Bali. Jurnal Skala Husada, 11(1), 34-40. Retrieved from https://www.google.com/url?sa=t\&rct=j\&q=\&esr $\mathrm{c}=\mathrm{s} \&$ source $=$ web\&cd=3\&ved $=2$ ahUKEwjtm $4 \mathrm{Kn}$ KXgAhVCpI8KHUS-

CngQFjACegQIBRAC\&url=http\%3A\%2F\%2Fpolte kkesdenpasar.ac.id\%2Ffiles\%2FJSH\%2FV11N1\%2FI $\% 2520$ Wayan $\% 2520 \mathrm{Jana} 1 \% 2 \mathrm{C} \% 2520 \mathrm{I} \% 2520 \mathrm{Ge}$ de\%2520Sudarmanto2\%2C\%2520Ni\%2520Ketu $\mathrm{t}$

Kalima, T. (2007). Keragaman Jenis dan Populasi Flora Pohon di Hutan Lindung Gunung Slamet, Baturraden, Jawa Tengah. Jurnal Penelitian Hutan Dan Konservasi Alam, IV(2), 151-160. Retrieved from http://ejournal.forda-mof.org/ejournallitbang/index.php/JPHKA/article/view/1196/11 18

Kusumaningtyas, R., \& Chofyan, I. (2012). Pengelolaan Hutan Dalam Mengatasi Alih Fungsi Lahan Hutan di Wilayah Kabupaten Subang. Jurnal Perencanaan Wilayah Dan Kota, 13(2), 1-11. Retrieved from https://ejournal.unisba.ac.id/index.php/planolog i/article/view/1389/861

Lane, L. J., Hernandez, M., \& Nichols, M. (1997). Processes controlling sediment yield from watersheds as functions of spatial scale. Environmental Modelling \& Software, 12(4), 355369.

https://doi.org/https://doi.org/10.1016/S13648152(97)00027-3

Lu, H., Moran, C. J., \& Sivapalan, M. (2005). A theoretical exploration of catchment-scale sediment delivery. Water Resources Research, 41(9), 1-15. https://doi.org/10.1029/2005WR004018

Macgregor, J., Masirembu, S., Williams, R., \& Munikasu, C. (2000). Estimating the Economic Value of Water in Namibia. Water, (November), 1-10.

Moore, R. D., Story, A. C., \& Spittlehouse, D. L. L. (2005). Riparian Microclimate and Stream Temperature Response to Forest Harvesting: A Review. Journal of the American Water Resources Association, 41(4), 813-834. https://doi.org/10.1111/j.17521688.2005.tb03772.x
Murtiono, U. H., \& Wuryanta, A. (2016). Telaah Eutrofikasi pada Waduk Alam Rawapening. In Priyono, A. N. Anna, A. A. Sigit, Y. Priyana, \& C. Amin (Eds.), Prosiding Seminar Nasional Geografi UMS 2016: Upaya Pengurangan Risiko Bencana Terkait Perubahan Iklim (pp. 170-181). Surakarta, Indonesia: Muhammdiyah University Press. $\quad$ Retrieved from https://publikasiilmiah.ums.ac.id/bitstream/han dle/11617/8231/16_Ugro Hari Murtiono.pdf?sequence $=1$

Mutasodirin, H. A. (2014). Nilai Ekonomi Air Hutan Pendidikan Gunung Walat dan Kontribusinya terhadap Masyarakat Sekitar. Institut Pertanian Bogor. Retrieved from http://repository.ipb.ac.id/jspui/bitstream/1234 56789/54898/9/E12bad.pdf

Ojea, E., Ortega, J. M., \& Chiabai, A. (2012). Defining and classifying ecosystem services for economic valuation: the case of forest water services. $E n v i$ ronmentals ci ence \& policy 19,19(20), $1-15$.

https://doi.org/doi:10.1016/j.envsci.2012.02.00 2

Pemerintah, R. I. Peraturan Pemerintah No. 82 Tahun 2001 tentang: Pengelolaan Kualitas Air dan Pengendalian Pencemaran Air (2001). Indonesia. Retrieved from http://www.hukumonline.com/pusatdata/detail /11857/node/546/peraturan-pemerintahnomor-82-tahun-2001

Presiden Republik Indonesia. Undang-undang Republik Indonesia Nomor 41 Tahun 1999 Tentang Kehutanan (1999). Indonesia: Lembaran Negara Republik Indonesia Tahun 1999 Nomor 167.

Pudjiharta, A. (2008). Pengaruh Pengelolaan Hutan pada Hidrologi (Influences of Forest Management on Hydrology). Info Hutan, V (2), 141-150.

Purwanto, Irfan Budi Pramono, S. Andy Cahyono, Agus Wuryanto, \& Sunaryo. (2009). Distribusi Spasial Nilai Ekonomi Hasil Air dari Hutan Lindung Baturraden. In G. A. Ngaloken, S. Gunadi, M. Molo, \& Pratiwi (Eds.), Teknologi, Sosial Ekonomi dan Kelembagaan Sebagai Basis Pengelolaan DAS (pp. 58-69). Purokerto: Pusat Penelitian dan Pengembangan Hutan dan Konservasi Alam.

Rusmanto, Nandang, \& Prasetyo, B. E. (1999). Pemetaan geologi lingkungan daerah Purwokerto dan sekitarnya, Jawa Tengah. Banudng.

Sadeghi, S. H., \& Saeidi, P. (2010). Fiabilité des courbes de transport sédimentaire d'un bassin versant forestier feuillu en Iran. Hydrological Sciences Journal, 55(5), 821-831. https://doi.org/10.1080/02626667.2010.48979 7

Soekartawi. (2014). Teori Ekonomi Produksi Dengan Pokok Bahasan Analisis Fungsi Coubb-Douglas. Jakarta: Divisi Buku Perguruan Tinggi, PT. Raja Grafindo Persada.

Sumargo, B. (2002). Perkembangan teori sewa tanah dalam perspektif pemikiran ekonomi. Journal The WINNERS, 3(2), 188-195. Retrieved from https://media.neliti.com/media/publications/16 4787-ID-perkembangan-teori-sewa-tanah-dalampers.pdf

Suparmoko. (1997). Ekonomi sumberdaya alam dan Lingkungan. BPFE. Yogyakarta, 1-366. Retrieved from 
https://www.goodreads.com/author/show/874 597.M_Suparmoko

Sylviani. (2008). Kajian Distribusi Biaya dan Manfaat Hutan Lindung Sebagai Pengatur Tata Air. Jurnal Penelitian Sosial Dan Ekonomi Kehutanan, 5(2), 95-109.

https://doi.org/https://doi.org/10.20886/jpsek. 2008.5.2.95-109

Tahvonen, O. (2000). Economic Sustainability and Scarcity of Natural Resources: A Brief Historical Review. Washington, D.C.: Resources for the Future. Retrieved from http://www.rff.org

Uly, F., Marsudi, \& Jati, D. R. (2001). Pengaruh Penggunaan Pupuk Terhadap Kualitas Air Tanah Di Lahan. Jurnal Teknologi Lingkungan Lahan Basah, 1(82), 1-10. Retrieved from http://jurnal.untan.ac.id/index.php/jmtluntan/ar ticle/view/8280

Verstraeten, G., \& Poesen, J. (2001). Factors controlling sediment yield from small intensively cultivated catchments in a temperate humid climate. Geomorphology, 40(1-2), 123-144. https://doi.org/10.1016/S0169-555X(01)00040$\mathrm{X}$

Visa, J., \& Harjana, T. (2015). Pola dan Distribusi Frekuensi Curah Hujan di Pulau Morotai Berbasis Data Satelit Tropical Rainfall Measuring Mission (TRMM). Jurnal Meteorologi Dan Geofisika, 16(1), 1-7. Retrieved from http://puslitbang.bmkg.go.id/jmg/index.php/jmg /article/download/258/179

Widianto, H., Noveras, D., Suprayogo, D., Widodo, R. H., Purnomosidhi, P., \& van Noordwijk, M. (2004). Konversi hutan menjadi lahan pertanian: apakah fungsi hidrologis hutan dapat digantikan sistem kopi monokultur? Agrivita, 26(1), 47-52. Retrieved from https://www.worldagroforestry.org/region/sea/ .../download 